NBER WORKING PAPER SERIES

\title{
NEW FRAMEWORK FOR MEASURING AND MANAGING MACROFINANCIAL RISK AND FINANCIAL STABILITY
}

\author{
Dale F. Gray \\ Robert C. Merton \\ Zvi Bodie \\ Working Paper 13607 \\ http://www.nber.org/papers/w13607
}

NATIONAL BUREAU OF ECONOMIC RESEARCH

1050 Massachusetts Avenue

Cambridge, MA 02138

November 2007

The views expressed herein are those of the author(s) and do not necessarily reflect the views of the National Bureau of Economic Research.

(C) 2007 by Dale F. Gray, Robert C. Merton, and Zvi Bodie. All rights reserved. Short sections of text, not to exceed two paragraphs, may be quoted without explicit permission provided that full credit, including $\odot$ notice, is given to the source. 
New Framework for Measuring and Managing Macrofinancial Risk and Financial Stability Dale F. Gray, Robert C. Merton, and Zvi Bodie

NBER Working Paper No. 13607

November 2007

JEL No. E44,G0

\begin{abstract}
$\underline{\text { ABSTRACT }}$
This paper proposes a new approach to improve the way central banks can analyze and manage the financial risks of a national economy. It is based on the modern theory and practice of contingent claims analysis (CCA), which is successfully used today at the level of individual banks by managers, investors, and regulators. The basic analytical tool is the risk-adjusted balance sheet, which shows the sensitivity of the enterprise's assets and liabilities to external "shocks." At the national level, the sectors of an economy are viewed as interconnected portfolios of assets, liabilities, and guarantees -- some explicit and others implicit. Traditional approaches have difficulty analyzing how risks can accumulate gradually and then suddenly erupt in a full-blown crisis. The CCA approach is well-suited to capturing such "non-linearities" and to quantifying the effects of asset-liability mismatches within and across institutions. Risk-adjusted CCA balance sheets facilitate simulations and stress testing to evaluate the potential impact of policies to manage systemic risk.
\end{abstract}

Dale F. Gray

International Monetary Fund and MF Risk

5921 Searl Terace

Bethesda, MD 20816

dgray@imf.org

Robert C. Merton

Graduate School of Business Administration

Harvard University, Baker Library 353

Soldiers Field Road

Boston, MA 02163

and NBER

rmerton@hbs.edu
Zvi Bodie

School of Management

Boston University

704 Commonwealth Avenue

Boston, MA 02215

zbodie@bu.edu 


\title{
New Framework for Measuring and Managing Macrofinancial Risk and Financial Stability
}

\author{
By \\ Dale F. Gray, Robert C. Merton, Zvi Bodie
}

\section{Introduction}

Vulnerability of a national economy to volatility in the global markets for credit, currencies, commodities, and other assets has become a central concern of policymakers. The responsibility for managing these risks at the national level often is given to the central bank. However, the conventional models and analytical tools used by central banks today are ill suited for analyzing these types of risk. This paper proposes a new approach to improve the way central banks can analyze and manage the financial risks of a national economy. It is based on the modern theory and practice of contingent claims analysis (CCA), which is successfully used today at the level of individual banks by managers, investors, and regulators. When applied to the analysis and measurement of credit risk, CCA is commonly called the Merton Model. ${ }^{1}$ The basic analytical tool is the risk-adjusted balance sheet, which shows the sensitivity of the enterprise's assets and liabilities to external "shocks." At the national level, the sectors of an economy are viewed as interconnected portfolios of assets, liabilities, and guarantees - some explicit and others implicit. Traditional approaches have difficulty analyzing how risks can accumulate gradually and then suddenly erupt in a full-blown crisis. The CCA approach is well-suited to capturing such "non-linearities" and to quantifying the effects of assetliability mismatches within and across institutions. Risk-adjusted CCA balance sheets facilitate simulations and stress testing to evaluate the potential impact of policies to manage systemic risk.

In addition to their traditional focus on inflation and output, central banks are increasingly focusing on the resilience of the national financial system. The CCA framework provides a forward-looking market-based set of indicators to measure the vulnerability of various sectors of the economy and is well-suited to capturing nonlinearities and to quantifying the effects of asset-liability mismatches within and across institutions.

The paper starts with a simple framework of CCA balance sheets for four key sectors (sovereign, financial, corporate, and household sectors). It describes how the sectoral CCA balance sheets can be constructed and linked together. Several different types of risk transmission channels are discussed.

\footnotetext{
${ }^{1}$ See Merton $(1973,1974,1977,1992,1998)$. Initially developed for valuation of corporate firms, CCA has been adapted to financial institutions and sovereigns.
} 


\section{Contingent Claims Analysis}

A contingent claim is any financial asset whose future payoff depends on the value of another asset. The prototypical contingent claim is an option - the right to buy or sell the underlying asset at a specified exercise price by a certain expiration date. A call is an option to buy; a put is an option to sell. Contingent claims analysis is a generalization of the option pricing theory pioneered by Black-Scholes (1973) and Merton (1973). Since 1973, option pricing methodology has been applied to a wide variety of contingent claims. In this paper we focus on its application to the analysis of credit risk and guarantees against the risk of default.

The contingent claims approach is based on three principles: (i) the values of liabilities are derived from assets; (ii) liabilities have different priority (i.e. senior and junior claims); and, (iii) assets follow a stochastic process. The liabilities consist of senior claims (such as senior debt), subordinated claims (such as subordinated debt) and the junior claims (equity or the most junior claim). As total assets decline, the value of risky debt declines and credit spreads on risky debt rise.

Balance sheet risk is the key to understanding credit risk and crisis probabilities. Default happens when assets cannot service debt payments. Uncertain changes in future asset value, relative to promised payments on debt, is the driver of default risk. Figure 1 illustrates the key relationships. The uncertainty in asset value is represented by a probability distribution at time horizon $\mathrm{T}$. At the end of the period the value of assets may be above the promised payments indicating that debt service can be made, or below the promised payments leading to default. The area below the distribution in Figure 1(a) is the "actual" probability of default. The asset-return probability distribution used to value contingent claims is not the "actual" one but the "risk-adjusted" or "risk-neutral" probability distribution, which substitutes the risk-free interest rate for the actual expected return in the distribution. This risk-neutral distribution is the dashed line in Figure 1(b) with expected rate of return r, the risk-free rate. Thus, the "risk-adjusted" probability of default calculated using the "risk-neutral" distribution is larger than the actual probability of default for all assets which have an actual expected return $(\mu)$ greater than the risk-free rate $r$ (that is, a positive risk premium). ${ }^{2}$

The calculations of the "actual" probability of default is outside the CCA/Merton Model but it can be combined with an equilibrium model of underlying asset expected returns to produce estimates that are consistent for expected returns on all derivatives, conditional on the expected return on the asset. The reason being that one does not have to know expected returns to use the CCA/Merton models for the purpose of value or risk calculations.

\footnotetext{
${ }^{2}$ See Merton (1992, pp.334-343; 448-450).
} 


\section{Figure 1}

The value of assets at time $t$ is $A(t)$. The asset return process is $d A / A=\mu_{A} d t+\sigma_{A} \varepsilon \sqrt{t}$, where $\mu_{A}$ is the drift rate or asset return, $\sigma_{A}$ is equal to the standard deviation of the asset return, and $\varepsilon$ is normally distributed, with zero mean and unit variance. The probability distribution at time $\mathrm{T}$ is shown in (a) below.

(a)

Asset Value

$\mathrm{A}_{0}$

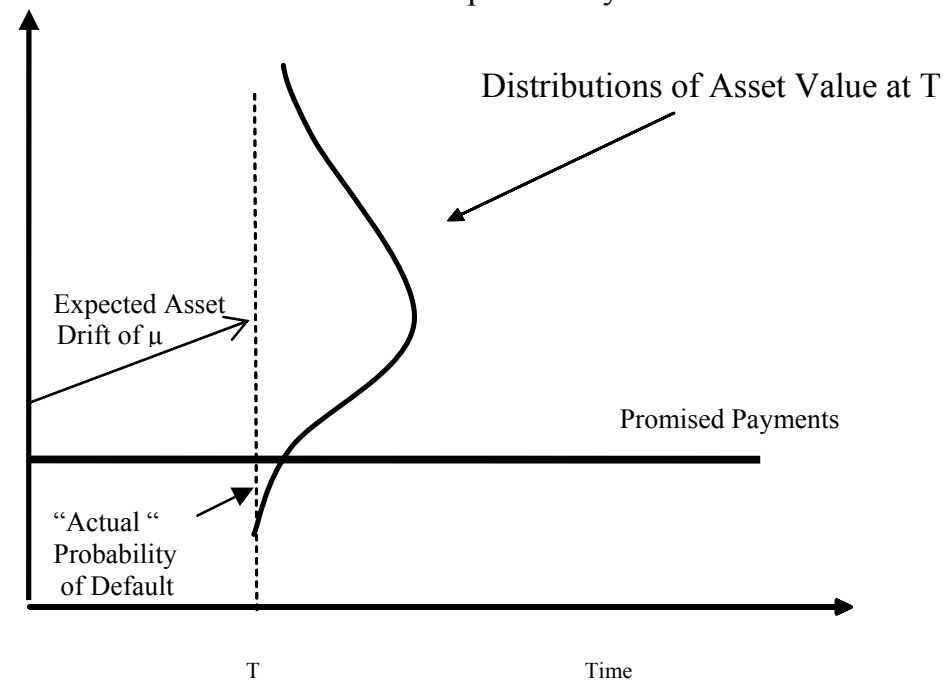

Default occurs when assets fall to or below the promised payments, $B_{t}$. The probability of default is the probability that $A_{t} \leq B_{t}$ which is:

$\operatorname{Prob}\left(A_{t} \leq B_{t}\right)=\operatorname{Prob}\left(A_{0} \exp \left[\left(\mu_{A}-\sigma_{A}^{2} / 2\right) t+\sigma_{A} \varepsilon \sqrt{t}\right] \leq B_{t}\right)=\operatorname{Prob}\left(\varepsilon \leq-d_{2, \mu}\right)$

Since $\varepsilon \sim N(0,1)$, the "actual" probability of default is $N\left(-d_{2, \mu}\right)$,

where $d_{2, \mu}=\frac{\ln \left(A_{0} / B_{t}\right)+\left(\mu_{A}-\sigma_{A}^{2} / 2\right) t}{\sigma_{A} \sqrt{t}} . N(\cdot)$ is the cumulative standard normal distribution.

Shown in (b) below is the probability distribution (dashed line) with drift of the risk-free interest rate, $\mathrm{r}$.

Risk adjusted probability of default is $N\left(-d_{2}\right)$, where $d_{2}=\frac{\ln \left(A_{0} / B_{t}\right)+\left(r-\sigma_{A}^{2} / 2\right) t}{\sigma_{A} \sqrt{t}}$.

(b)

b)

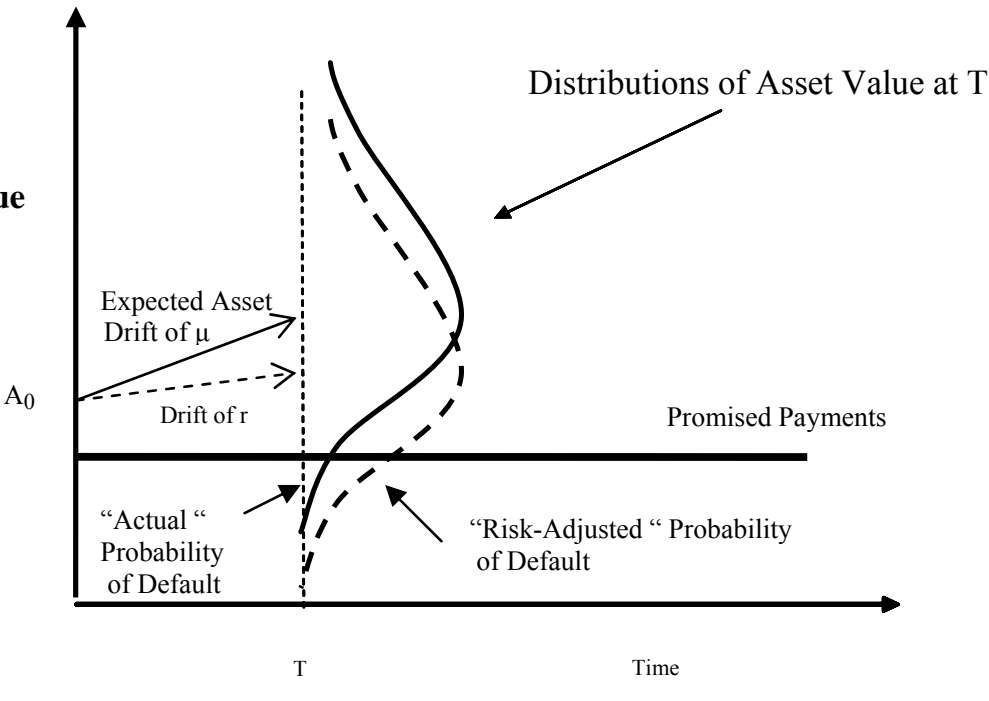


Box 1 presents the Merton Model equations.

\section{Box 1 Merton Model Equations for Pricing Contingent Claims}

The total market value of assets at any time, $t$, is equal to the market value of the claims on the assets, equity and risky debt maturing at time $T$ :

$$
\begin{gathered}
\text { Assets }=\text { Equity }+ \text { Risky Debt } \\
A(t)=J(t)+D(t)
\end{gathered}
$$

Asset value is stochastic and in the future may decline below the point where debt payments on scheduled dates cannot be made. The equity can be modeled and calculated as an implicit call option on the assets, with an exercise price equal to the promised payments, $B$, maturing in $T$ - $t$ periods. The risky debt is equivalent in value to default-free debt minus a guarantee against default. This guarantee can be calculated as the value of a put on the assets with an exercise price equal to $B$.

$$
\begin{gathered}
\text { Risky Debt }=\text { Default-Free Debt }- \text { Debt Guarantee } \\
\qquad(t)=B e^{-r(T-t)}-P(t)
\end{gathered}
$$

We omit the time subscript at $\mathrm{t}=0$.

The value of the equity is computed using the Black-Scholes-Merton formula for the value of a call:

$$
\begin{gathered}
J=A N\left(d_{1}\right)-B e^{-r T} N\left(d_{2}\right) \\
d_{1}=\frac{\ln \left(\frac{A}{B}\right)+\left(r+\frac{\sigma^{2}}{2}\right) T}{\sigma \sqrt{T}} \text { and } d_{2}=d_{1}-\sigma \sqrt{T}
\end{gathered}
$$

$r$ is the risk-free rate

$\sigma$ is the asset return volatility

$N(d)$ is the cumulative probability of the standard normal density function below $d$.

The formula for the "delta" of the put option is $N\left(d_{1}\right)-1$.

The yield to maturity on the risky debt, $\mathrm{y}$, is defined by: $\quad D=B e^{-y T}$

$$
y=\frac{\ln (B / D)}{T}
$$

And the credit spread is $s=y-r$

The "risk-neutral" or "risk-adjusted" default probability is $N\left(-d_{2}\right)$.

Example: Assuming that: $A=\$ 100, \sigma=0.40(40 \%), B=\$ 75, r=0.05(5 \%), T=1$ (one year), the value of the equity is $\$ 32.367$, the value of risky debt is $\$ 67.633$; the yield to maturity on the risky debt is $10.34 \%$, and the credit spread $5.34 \%$. The risk adjusted probability of default is $26 \%$.

(See Annex for more details including extensions of the Merton Model.) 
Financial fragility is intimately related to probability of default. Shocks to flows, prices, or liquidity frequently end up being converted into credit risk in a crisis. Default is hard to handle in traditional macro models in part due to assumptions which usually exclude the possibility of default. In addition, flow-of-funds and accounting balance sheets cannot provide measures of risk exposures which are forward-looking estimates of losses. CCA is a framework that explicitly includes the probability of default.

\section{Contingent Claim Balance Sheets for Sectors}

We view an economy as a set of interrelated balance sheets with four types of aggregate sectors - corporate, financial, household, and sovereign. The same general principles of contingent claims that apply to analysis of a single firm can also be applied to an aggregation of firms. The liabilities of a firm, a portfolio of firms in a sector, or the sovereign (combined government and monetary authorities) can be valued as contingent claims on the assets of the respective firm or sector or sovereign. The corporate sector refers to an aggregation of all non-financial firms. Treating the corporate sector as one large firm and the financial sector as one large institution a very simplified way of looking at the balance sheet but we will initially start out with this stylized framework to illustrate risk characteristics of the sector for the purposes of this analysis. Later in the paper we will look at the major financial institutions separately and group the corporate firms into sub-sectors. The key elements of the balance sheets for the corporate, financial, household, and sovereign sectors are shown in Figure 2. 
Figure 2 - Balance Sheets for the Corporate, Financial, Household, and Sovereign Sectors

ASSETS

CORPORATE SECTOR

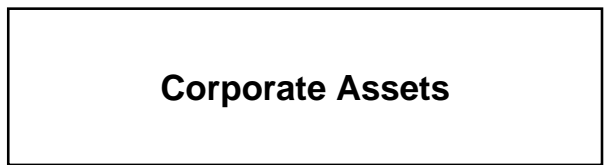

FINANCIAL SECTOR

Loans and other Assets

(including loans to corporates, households and sovereign)

Financial Guarantees

\section{LIABILITIES}
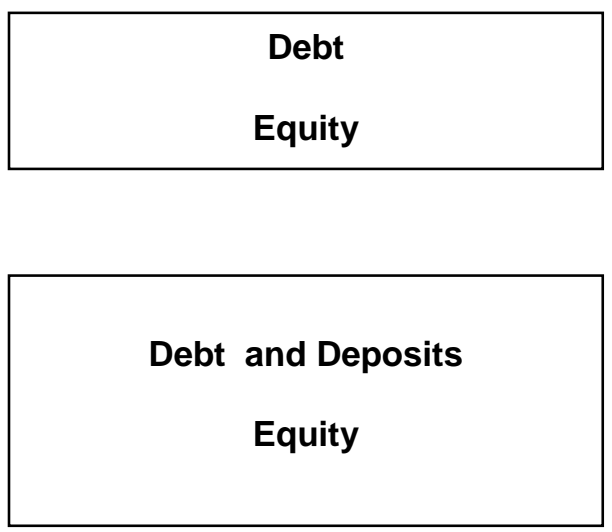

\section{HOUSEHOLD SECTOR}

Household Assets

(including household income and savings in the form of deposits and other financial assets)

Net Worth (Subsidiary BS)

Household Real Estate Assets
Household Net Worth - Claim on Household Assets

Consumption is a "Dividend"

Payment out of Asset Associated With this Claim

Household Mortgage and Debt Net Worth (Subsidiary BS)

SOVEREIGN (Government and Monetary Authorities)

Foreign Currency Reserves

Net Fiscal Asset

(PV of taxes minus expenditures)

Other Public Assets
Financial Guarantees

Foreign-currency Debt

Base Money and Local-currency Debt 


\section{Economy-wide Macro Contingent Claim Balance Sheets and Risk Exposures}

Building upon the theory of contingent claims laid out above, the macrofinance valuation identities use put-call parity relationships, which state that the asset value $A$ of each sector is equal to the value of its equity plus the value of its risky debt. ${ }^{3}$ The four primary sectors of the economy, for the corporate, financial, sovereign, and household balance sheets, are complemented by the foreign sector. The CCA balance sheet equations for each sector $j$ have the sector assets equal to equity (i.e. junior claims) plus risky debt. The function $E_{j}$ refers to the period $t$ value of sector $j$ 's equity (i.e. the junior claim), which is modeled as an implicit call option. The horizon period is $T$ for the calculation of the implicit option values. Risky debt, $D_{j}$, is equal to the default-free value of the debt, denoted by $\bar{B}_{i}\left(\bar{B}_{i} \equiv B_{i} e^{-r T}\right)$, minus the value of the implicit put option, which is denoted by $P_{j}$ (the expected losses associated with the debt). The time horizon $T$ is the same for all sectors for the calculation of the CCA values at each point in time. Using the notation above, the following equations state the put-call-parity relationships for the four domestic sectors. For the corporate sector (C), assets $A_{C}$ equal equity $E_{C}$ plus the risky debt $\left(\bar{B}_{C}-P_{C}\right)$ :

$$
A_{C}=E_{C}+\left(\bar{B}_{C}-P_{C}\right)
$$

For the financial sector $(\mathrm{F})$, assets $A_{F}$ plus contingent financial support from the sovereign $\alpha P_{F}$ equals equity $E_{F}$ plus the value risky debt/deposits $\left(\bar{B}_{F}-(1-\alpha) P_{F}\right)$

$$
A_{F}+\alpha P_{F}=E_{F}+\left(\bar{B}_{F}-(1-\alpha) P_{F}\right)
$$

$P_{F}$ is the implicit put option to the financial sector. ${ }^{4}$ The model assumes that the government's contingent liability, the value of the explicit or implicit sovereign guarantee, is a fraction $\alpha$ of the total $P_{F}$ and the remainder, $(1-\alpha) P_{F}$, is credit risk remaining in the debt and deposits of the financial sector.

For the sovereign, the assets of the sovereign $A_{S}$ include: foreign currency reserves $R_{M A}$ the net fiscal asset $A_{G}$ (defined as the present value of taxes and revenues, including seigniorage, minus the present value of government expenditures); and other public assets $A_{\text {Other }}$. The liabilities of the sovereign include base money $M_{B M}$ and risky local-currency $\operatorname{debt}\left(\bar{B}_{S L C}-P_{S L C}\right)$ and risky foreign-currency debt $\left(\bar{B}_{S F X}-P_{S F X}\right)$ and financial guarantees/contingent liabilities $\alpha P_{F}$ as shown below:

\footnotetext{
${ }^{3}$ See Gray et. al. (2002) and Gapen et. al. (2004).

${ }^{4}$ Merton (1977) was the first to demonstrate that the government's guarantee to banks could be modeled as an implicit put option.
} 


$$
A_{S}=R_{M A}+A_{G}+A_{\text {Other }}=M_{B M}+\left(\bar{B}_{S L C}-P_{S L C}\right)+\left(\bar{B}_{S F X}-P_{S F X}\right)+\alpha P_{F}
$$

For the household sector, the household asset $A_{H}$ is the sum of the household sector's financial wealth $A_{F I N}$, the present value of its labor income $A_{L}$, and equity $E_{H, R E}$ in real estate. The debt of households to banks and non-banks is frequently tied to homes and real estate. For this reason it is practical to have two segregated but linked household CCA balance sheets. The "subsidiary" balance sheet would have real estate as the primary asset and related debt would be on the liability side. ${ }^{5}$ The households "equity" in real estate is modeled as real estate assets $A_{H . R E}$ minus risky household mortgage related debt $\left(\bar{B}_{H, R E}-P_{H, R E}\right)$.

$$
\begin{aligned}
A_{H} & =A_{F I N}+A_{L}+E_{H, R E} \\
& =A_{F I N}+A_{L}+\left(A_{H, R E}-\left(\bar{B}_{H, R E}-P_{H, R E}\right)\right) \\
& =E_{H}+c_{H}
\end{aligned}
$$

The household sector asset $A_{H}$ is equal to the household net worth $E_{H}$ plus $C_{H}$ which is consumption modeled as a "dividend" payment out of the household asset up to time T.

The four sector CCA balance sheets can be integrated together into an economywide balance sheet as shown in Figure 3. For each sector, the assets, plus contingent assets (or minus contingent liabilities), minus equity/junior claims, minus risky debt sum to zero (down the column in Figure 3). These interlinked economic balance sheets demonstrate the interdependence among sectors; with one sector "long" a certain implicit option (plus sign) and another sector "short" the same implicit option (minus sign). For example, the economic balance sheet of the banking sector has assets consisting of corporate loans (default-free debt minus the value of a put option). The banking sector also includes contingent liabilities (implicit put options) from the government as an asset, which is an obligation (short put option) on the government's economic balance sheet. ${ }^{6}$

\footnotetext{
${ }^{5}$ There are many variations of this structure. Debt could be including on the main household balance sheet or additional subsidiary balance sheets could be included relating specific debt obligations to related assets. ${ }^{6}$ Macrofinancial risk models similar to this framework have been calibrated for over 20 countries (only a few with the household sector, however).
} 


\section{Figure 3 Economy-wide Contingent Claim Balance Sheet with Risk Exposures Across Sectors (Implicit Put and Call Options)}

\begin{tabular}{|c|c|c|c|c|c|}
\hline & Corp & Households & Financial & Sovereign & Foreign \\
\hline Asset & $A_{C}$ & $\begin{array}{l}A_{F I N} \\
+A_{L} \\
+\left(A_{H, R E}\right. \\
-\bar{B}_{H, R E} \\
\left.P_{H, R E}\right)\end{array}$ & $A_{F}$ & $\begin{array}{l}R_{F X} \\
+A_{G} \\
+A_{S, \text { Other }}\end{array}$ & \\
\hline $\begin{array}{l}\text { Cont. } \\
\text { A \& L }\end{array}$ & & & $+\alpha P_{F}$ & $-\alpha P_{F}$ & \\
\hline $\begin{array}{l}\text { Equity/ } \\
\text { Jr. \& } \\
\text { Sub. } \\
\text { Claims }\end{array}$ & $-E_{C}$ & $\begin{array}{l}-E_{H} \\
-C_{D}\end{array}$ & $-E_{F}$ & $\begin{array}{l}-M_{B M} \\
-\bar{B}_{S L C} \\
+P_{S L C}\end{array}$ & \multirow{3}{*}{$\begin{array}{c}\text { Foreign } \\
\text { Claims }\end{array}$} \\
\hline Barrier & $-\bar{B}_{C}$ & & $-\bar{B}_{F}$ & $-\bar{B}_{S F X}$ & \\
\hline $\begin{array}{l}\text { EL } \\
\text { (Put) }\end{array}$ & $+P_{C}$ & & $+\left(1-\alpha_{G}\right) P_{F}$ & $+P_{S F X}$ & \\
\hline Sum & 0 & 0 & 0 & 0 & 0 \\
\hline
\end{tabular}

The financial assets of the sectors can be separated into claims on foreigners and claims on domestic entities. For simplicity, the detailed cross-holdings by the household sector, financial sector, and foreign sector on the other sectors is not shown in Figure 3.

\section{Interrelationship of Macro Financial Contingent Claim Balance Sheets, Risk Exposures and Traditional Macroeconomic Flows}

We now show how the traditional macroeconomic flow-of-funds can be recovered from the CCA equations when risk goes to zero. Note that when the volatility of assets in the CCA balance sheet equations (Figure 3) is set to zero, the values of the implicit put options go to zero. ${ }^{7}$ The result is the accounting balance sheet of the sectors. The flow of

${ }^{7}$ If the volatility of assets goes to zero, we have the result that in the put option formula $N\left(-d_{1}\right)=N\left(-d_{2}\right)=0$ which means that the implicit put option values in the sectors go to zero. The measurement of the expected loss and credit risk is not possible with asset volatility set to zero. The second important observation is that if volatility goes to zero, $N\left(d_{1}\right)=N\left(d_{2}\right)=1$, and the value for the junior claim of the representative sector then reduces to the accounting "net worth" equal to deterministic assets minus a measure of the book value of debt. (See Gray and Malone (forthcoming) for details.) 
funds can thus be seen as a special deterministic case of the CCA balance sheet equations when volatility is set to zero and annual changes are calculated. Note that it is the implicit put options in risky debt and contingent liabilities that allow for risk to be transmitted between sectors in the CCA model. Without volatility the risk transmission between sectors is lost.

The combined accounts - income/flow, mark-to-market balance sheets, and risk exposure measures - comprise the three important sets of interrelated accounts in the economy which are somewhat similar to the accounts in large modern financial institutions. ${ }^{8}$ Risk managers would find it difficult to analyze the risk exposure of their firm or financial institution by relying solely on the income and cash flow statements, and not taking into account (mark-to-market) balance sheets or information on their institution's derivative or option positions. Country risk analysis that relies only on macroeconomic flow-based approach is deficient in a similar way, given that the traditional analysis does not take into account the volatility of assets.

\section{Measuring Implied Asset Value and Volatilities Using Market Prices}

The market value of assets of corporations, financial institutions, or sovereigns cannot be observed directly. However, from the observed prices and volatilities of market-traded securities, one can estimate the implied values and volatilities of the underlying assets. ${ }^{9}$ These implied asset values and asset volatilities can be used to calibrate the pricing and risk model of major sectors in the economy. We will discuss briefly how this can be done first for firms and financial institutions, then for the sovereign.

\section{Firms and Financial Institutions}

Domestic equity markets provide pricing and volatility information for the calculation of implied assets and implied asset volatility in corporate, bank and non-bank financial institutions. The simplest method solves two equations for two unknowns, asset value and asset volatility. Details are shown in Annex and in Merton (1974) and Crouhy et. al. (2000). Levonian (1991) used explicit option prices on bank equity to measure equity volatility and calibrate Merton Models for banks. Moody's-KMV has successfully applied its version of the CCA model to measure the implied assets values and volatilities and to calculate expected default frequencies (EDFs) for over 50,000 firms and financial institutions in 55 countries around the world KMV (1999 and 2001).

\footnotetext{
${ }^{8}$ Enterprise Risk Management is a framework to comprehensively measure and manage risk in firms and financial institutions whose use has expanded in recent years.

${ }^{9}$ An implied value refers to an estimate derived from other observed data. Techniques for using implied values are widely practiced in options pricing and financial engineering applications. See Bodie and Merton (1995).
} 
For unlisted corporates and banks, the relationship between the accounting information and the risk indicators, of companies with traded equity, can be used as a guide to map accounting information of companies without traded equity to default probabilities and risk indicators for institutions that do not have traded equity. (An example is Moody's RiskCalc for corporate sectors in many countries and for banks in the US.)

\section{Sovereign}

Since the market value of sovereign assets cannot be observed directly, a similar calibration procedure can be used for the sovereign balance sheet to estimate implied sovereign assets and asset volatility. The prices in the international markets (including foreign currency market), together with information from domestic market prices, provide the market information for the value and volatility of certain liabilities on the sovereign balance sheet. ${ }^{10}$ If we subtract the financial guarantees from both sides of the sovereign balance sheet at the bottom panels in Figure 2, the remaining sovereign liabilities are structured in a way that is consistent with the CCA framework. On the simplified sovereign balance sheet, the local-currency debt of the government, held outside of the monetary authorities, and base money are local-currency liabilities which are modeled as a call option on the sovereign assets with the default barrier derived from the foreign-currency debt. A simple two claim CCA framework is used to calibrate the sovereign balance sheet by calculating implied sovereign assets, $V_{\text {Sovereign }}$, and asset volatility. This calibrated risk-adjusted balance sheet can be used to estimate credit risk in sovereign foreign-currency and local-currency debt as well as other risk indicators. These indicators are found to be robust measures of sovereign credit risk. ${ }^{11}$ Scenarios and simulations can be carried out to evaluate the impact of fiscal and debt management policies and the impact of risk transfer onto the sovereign balance sheet.

\section{Household Sector Balance Sheet}

Modeling household balance sheets using the principles of CCA is much more difficult than for firms, financial institutions, or sovereigns. There is no traded equity of households, so techniques to use equity to imply assets are not possible. To construct the household balance sheet one alternative is to use a "bottom-up" approach. In the household sector, we can use macroeconomic data and information from household surveys to construct measures of the portfolio of household assets directly, for the most part, and try to estimate the volatility of household assets directly. Household balance sheet assets include financial assets (pension assets, annuities, mutual funds, bank deposits, etc.) and estimated labor income, i.e. the present value of expected labor income (see Gray and Malone (forthcoming)). For the household "subsidiary" balance sheet, direct estimation of the real estate prices, volatilities and debt obligations is likely to be the most practical (but admittedly difficult) approach. Ideally this analysis should be

\footnotetext{
${ }^{10}$ See Gray, Merton, Bodie (2002 and 2006).

${ }^{11}$ Applications to a wide range of countries are described in Gapen et. al. (2004 and 2005) and Gray, Merton, Bodie (forthcoming). Extensions to model the valuation of sovereign local-currency debt are described in Gray and Malone (forthcoming) and Gray, Lim, Loukoianova, Malone (IMF, forthcoming).
} 
carried out, not for one household sector, but for households segmented by income groups. $^{12}$

\section{Some Important Extensions and Refinements of CCA Models}

Numerous extensions of the original Merton Model have been developed that relax certain assumptions in the original model. These extensions are described in more detail in Annex but two extensions are important to mention here.

First, recent research has studied the relationship between the volatility skew implied by equity options and CDS spreads (Hull et. al. 2003). They establish a relationship between implied volatility of two equity options, leverage and implied asset volatility. This approach is, in fact, another way of implementing Merton's model to get spreads and risk-neutral default probabilities directly from the implied volatility of equity options. When the probability distributions derived from the option prices are negatively skewed (left-tailed) this means that the implied underlying asset distribution is negatively skewed which results in a higher probability of assets being below the distress barrier and thus higher spreads (Zou 2003). In a parallel way in the sovereign CCA application, the probability distributions derived from FX option prices show that more negatively skewed FX distributions are associated with higher sovereign credit risk in emerging markets (See Gray, Merton, and Bodie forthcoming). What is important about this is that the CCA framework is able to link information from equity and FX options to credit risk and spreads. Financial stability reports usually look separately at credit risk indicators and probability distributions from option prices, and associated market sentiment indicators like the VIX. CCA provides a structural framework linking the option price information to skews in implied asset distributions and thus to credit risk.

Second, the Merton Model has been extended to include stochastic interest rates. For example, Shimko, Tejima, and Van Deventer (1993) include a Vasicek interest rate term structure model which allows interest rates and term structure of interest rates to vary. This closed form model, called the Merton-STV model, is a very useful extension which links the impact of changing interest rate levels, volatilities, and term structures to credit risk in financial institutions and corporations.

\section{Measuring Risk Exposures}

So far, we have discussed how to calculate the value of risky debt, guarantees, and equity using the CCA approach. We now turn to how to measure the risk exposures. The values of the contingent claims on the CCA balance sheets contain embedded implicit options which can be used to obtain certain risk measures. These include risk exposures in risky debt, probabilities of default, distance-to-distress, spreads on debt, and

\footnotetext{
12 It may be very difficult to model households in this way due to data limitations in many countries. CCA balance sheets for households are not as accurate as the corporate or bank or sovereign CCA balance sheet models.
} 
the sensitivity of the implicit options to the change in the underlying asset and other measures. The implicit put option increases in a non-linear way as the market value of the sector's assets decline. ${ }^{13}$ The delta measures this non-linear change in the value of an option per unit change in the value of the underlying asset as illustrated in Figure 4.

\section{Figure 4}

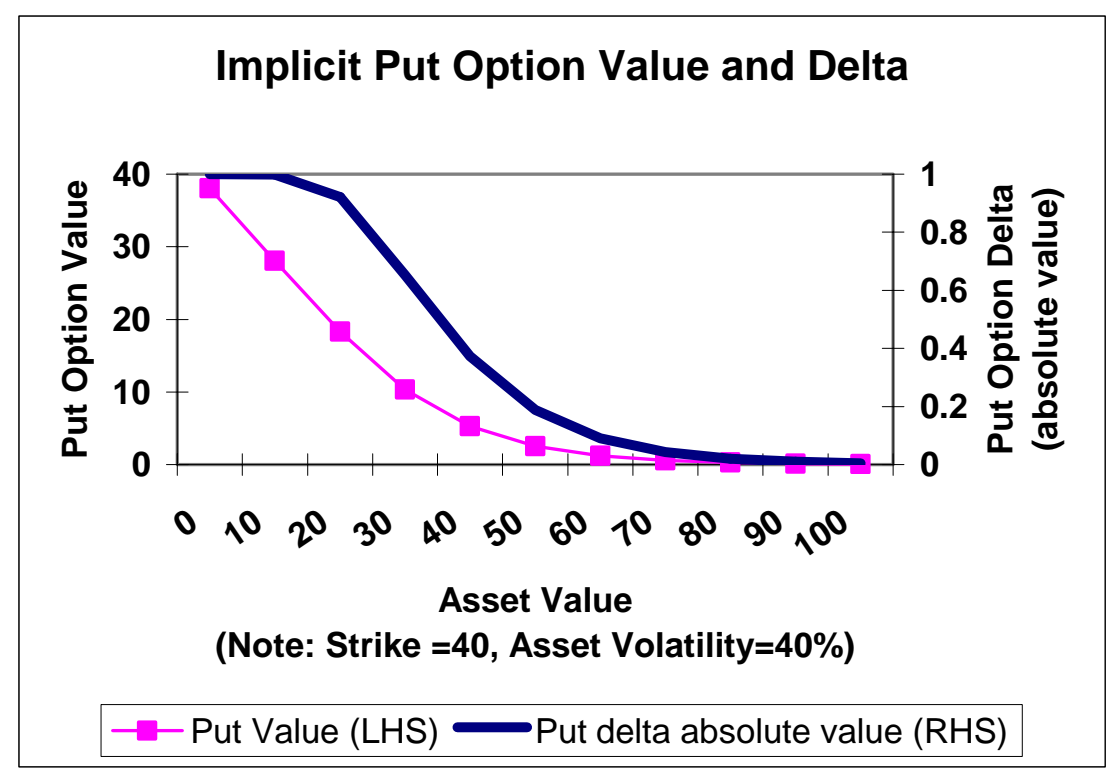

For example, the government's exposure to its guarantee to the banking sector can be measured with the delta of the banking sector implicit put option. There are other important sensitivity measures for risk exposures. The gamma is the change of the delta with respect to the underlying asset. The vega is the sensitivity of the change in the implicit option with respect to a change in asset volatility. These sensitivity measures of risk exposures could be useful new indicators of the potential for financial instability.

\section{Risk Transmission between Sectors}

The framework described above is versatile and can be used to understand many types of crises and risk shifting that cannot as easily be analyzed with other techniques. The risk-transmission patterns can be dampened or may be magnified depending on the capital structure and linkages. The framework can help identify situations where volatility gets magnified and negative feedback loops that can trigger severe crises. The patterns of value and default correlation across different asset classes, sectors and sovereign debt values depend on these structures and links, unique to a particular economy. Below are some examples of risk transmission between sectors.

\footnotetext{
${ }^{13}$ See Draghi et. al. (2003).
} 


\section{Risk Transmission from the Corporate Sector to the Banking Sector}

The corporate sector's financial distress - possibly caused by stock market decline, recession, commodity price drops, or excessive unhedged foreign debt accompanied by currency devaluation - can be transmitted to the financial sector. The value of the assets of the corporate sector declines, so does the value of the debt (and equity) which leads to a decline in bank assets and an increase in banking sector credit risk.

\section{Risk Transfer}

\section{Corporate Sector $\longrightarrow$ Banking Sector}

The household sector can also transmit risk to the banking sector in a similar manner. The implicit put option in the banking sector derives its value from banking assets which have embedded put options in risky loans to borrower.

\section{Risk Transmission from the Banking Sector to the Government}

The banking sector's financial distress, such as systemic banking crises and/or deposit runs can be transmitted to the government by increase in the value of the guarantees.

Risk Transfer

\section{Banking Sector $\quad \longrightarrow$ Government}

Banking sector distress from non-performing loans or a deposit run can result in a large increase in the government's implicit guarantee. ${ }^{14}$

\section{Risk Transmission from the Government to the Banks and Feedback}

The government's financial distress or default can transmit risk to the financial system. For example, when the banking sector is holding a significant proportion of government securities, and there is a negative shock to the government financial position, it can have a detrimental impact on the banks. The government's implicit guarantee is also likely to increase. This, in turn, makes the government financial position worse, creating a compounding effect, which may result in the government's failure to honor its guarantee obligations and cause a collapse of the banking system.

Risk Transfer

\section{Banking/Financial System}

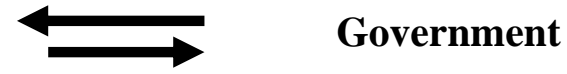

The vicious cycle could arise, when the lower value of government securities lowers bank assets, and raises the implicit financial guarantee, which in turn lowers government assets further. A similar process could occur if banks have significant lending denominated in foreign exchange and a weak government position causes a

${ }^{14}$ See Merton and Bodie (1992). 
depreciation of the exchange rate, the depreciation worsens the position of the banks raising the implicit guarantee, which in turn lowers government assets further. This means that the implicit guarantee is higher than what is shown above. In some situations, this vicious cycle can spiral out of control, eventually resulting in the inability of the government to provide sufficient guarantees to banks and leading to a systemic financial crisis.

\section{Risk Transmission from the Pension System to the Government}

The financial distress related to pension plans can result in the transmission of risk to the government.

\section{Risk Transfer}

\section{Pension System $\longrightarrow$ Government}

We assume that the pension system is a defined benefit plan which has an implicit government guarantee. A decline in corporate assets would cause the corporate equity value to drop. This, in turn, increases the government guarantee to the pension system and the implicit guarantee to banks. ${ }^{15}$

\section{$\underline{\text { Risk Transmission from the Sovereign to Holders of Sovereign Debt }}$}

Fiscal, banking and other problems can cause distress for the government which can transmit risk to holders of government debt.

Risk Transfer

\section{Sovereign $\longrightarrow$ Debt Holders (sovereign foreign currency denominated debt or sovereign local currency denominated debt)}

Holders of foreign-currency debt have a claim on the value of the debt minus the potential credit loss, which is dependent on the level of assets of the sovereign (in foreign currency terms) compared to the foreign-currency default barrier. Higher spreads demanded by the debt holders to cover the credit risk in government debt could lead to higher interest rates on government debt which could lead to a depreciation and feedback potentially further worsen the sovereign's financial position.

\section{Risk Transmission from the Markets to the Household Sector and then to Consumption}

Changes in the value of financial assets and real estate owned by households affect the value of household assets and have an impact on consumption.

\footnotetext{
${ }^{15}$ See Bodie (2006).
} 
Risk Transfer

Financial and Real Estate

Markets $\longrightarrow$ Household Assets $\longrightarrow$ Consumption

The CCA models for households could provide useful insights into household behavior regarding consumption, especially how consumption changes with household asset volatility (and higher moments of the household asset distribution). This is because the CCA captures non-linearities in the value of household debt and in the changes in consumption.

\section{Potential Highly Non-Linear Risk Transmission when Assets of One Sector are} Linked (through Implicit Put Options) to the Assets of Another Sector

Risk is transmitted across the sectors and balance sheets through the implicit put options in risky debt and guarantees. Risky debt contains an implicit put option. If this risky debt is linked to the asset of another sector (e.g. through loans from the financial sector), the risky debt of the second sector (e.g. banks) becomes a function of the implicit put option of the first sector. In other words it is a compound put option. The compound nature of the implicit put options of interlinked sectors creates the potential for highly non-linear risk transmission. An illustration of this is shown in Box 2.

The dynamics of the interlinked CCA risk-adjusted balance sheets provide useful insights into the asymmetric nature of value changes and risk transmission in business cycle expansions versus contractions. In a situation of rapid economic growth, asset and equity values on balance sheets trend upward. A stress event somewhere in the system can set off a chain reaction of defaults as the implicit put options are "exercised." The compound nature of the implicit put options can cause a sudden sharp decline in values of risky debt or sharp increase in implicit guarantees. There is thus an asymmetry in the change in values in the stress or crisis period as compared to the smoother rate of change in the build-up phase of the business cycle. 


\section{Box 2 Highly Non-linear Risk Exposures from Interlinked Sectors}

The risky debt of sector one, $\mathrm{S} 1$, is the default free value of debt minus and implicit put option which we will assume is the asset of sector two, S2, i.e. $\left(\bar{B}_{s 1}-P_{s 1}\right)=A_{s 2}$. In sector two the assets are equal to equity plus risky debt, $A_{s 2}=E_{s 2}+\left(\bar{B}_{s 2}-P_{s 2}\right)$. If we combine these equations and rearrange, we can see that the implicit put option, i.e. the present value of expected losses associated with the debt of $\mathrm{S} 2$, is a function of the implicit put option in $\mathrm{S} 1$.

$P_{S 2}=f\left(\left(\bar{B}_{S 1}-P_{S 1}\right)\right.$, volatility $\left._{A, S 2}, \bar{B}_{S 2}, r, t\right)$.

Let's take an example of this relationship by looking at bank loans to borrowers whose risky debt can be modeled as default-free value of the loan minus an implicit put option (derived from the borrower's asset level, asset volatility, and leverage). The bank's risk exposure derives from a compound put option since it depends on the bank assets whose value depends on the borrower's risky debt. This compound option can lead to highly non-linear risk exposures. Let's take a simple example where a bank's assets consist $100 \%$ of risky debt to a corporate sector with promised payments of 100. The Figure below illustrates how the value of the bank's implicit put option increases as: (i) the corporate sector debt to asset ratio increases; and (ii) the volatility of the corporate assets increases.

\section{Bank Expected Losses (implicit put option) vs. Corporate Sector Debt to Asset Ratio for} High and Low Volatility of Corporate Assets

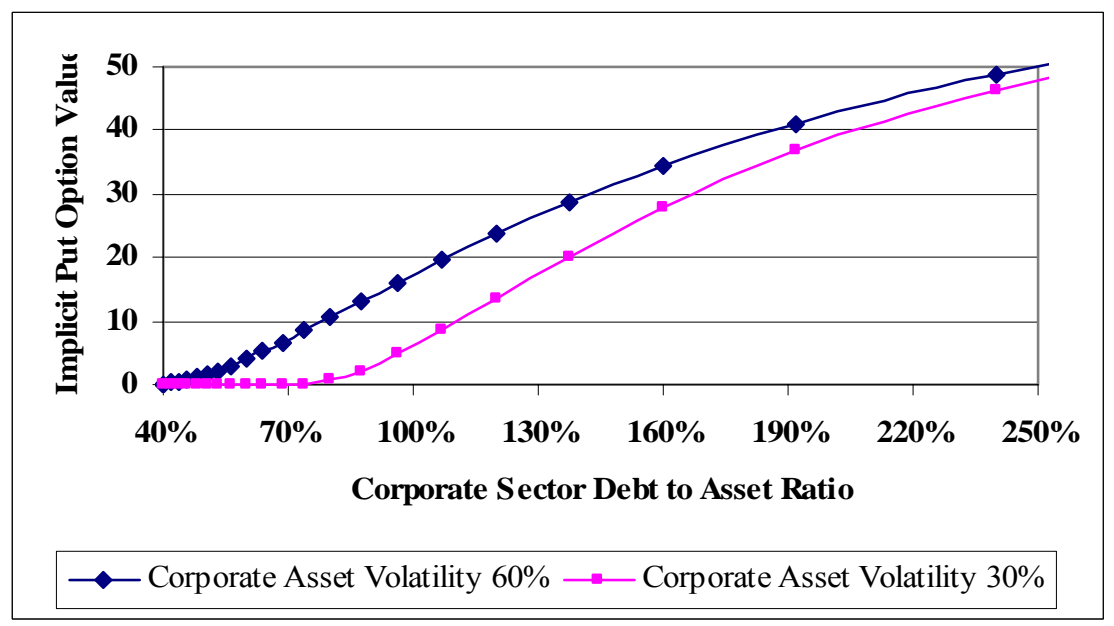

This means the (absolute value) of the delta of the bank's implicit put option is high when the volatility of corporate assets is high and is high even when the corporate debt to asset ratio is low. While this is just a stylized example, the non-linear nature of the implicit put options was clearly evident in the Thailand crisis. There were high levels of foreign currency denominated debt in the corporate sector in Thailand in 1996. In 1997, devaluation, combined with a decline in the stock market and increased volatility led to widespread bankruptcies which transmitted risk to bank balance sheets and on to the government via the implicit guarantee. The implicit government guarantee to the banking system was 3\% of GDP in 1996 and increased to over 35\% of GDP following the 1997 devaluation (Gray 2001). 


\section{Balance Sheet Risk Framework for Stress Testing, Scenario, and Simulation Analysis}

The economy-wide CCA model can be used with scenario, simulation, and stresstesting analysis. There are different levels of aggregation of the sectors, which range from the simple four sector model described earlier, to a model with several corporate subsectors, household sectors broken into different income groups, and several financial sector sub-sectors. The level of aggregation depends on practical issues related to data availability, data reliability, and the goals of the analysis. By simulating shocks to key variables, one can see how the CCA risk indicators and implicit put and call options are affected in other sectors.

The structure and aggregation of CCA models can be designed to analyze risk in major financial institutions for financial stability analysis. Since distress in one major institution can impact systemic stability, it makes sense to try to model the risk for major institutions individually and group smaller financial institutions to keep the model size manageable.

There are different ways to link these financial institutions to other sectors and to macroeconomic variables and use the model for stress testing. Some examples are described below.

\section{Example of Financial Stability Stress-Testing with CCA Model, Factor} Model and Macro Model - First, a CCA model is calibrated for each major financial institution (or groups of institutions) using equity market information and the time series of implied assets and risk indicators is calculated (calibration can be done using the Merton Model, Hull's implementation of the Merton model, or another CCA model). The time pattern of asset returns of each financial institution (or of the risk indicators) can be used as the dependent variable in a factor model. Key factors driving these asset returns could include GDP, domestic and foreign interest rates, exchange rate, domestic and foreign equity indices, etc. A separate macroeconomic scenario generating model, e.g. a macroeconomic VAR or GVAR model, ${ }^{16}$ could then be used to test the impact of scenarios on the key factors, which feed into the financial institution's assets. This, in

turn affects the credit risk indicators and the value of equity capital. ${ }^{17}$ This stress-testing process is described in Figure 5.

\footnotetext{
${ }^{16}$ VAR models used for stress testing are discussed in Hoggarth et. al. (2005). GVAR models were used to generate scenarios for credit risk analysis in Pesaran et. al. (2004) and Castren et. al. (2007).

${ }^{17}$ The model used by Gray and Walsh (forthcoming) is similar to this approach. Also see IMF (2006).
} 


\section{Figure 5 Stress-testing Process}

\begin{tabular}{|c|c|c|c|}
\hline Step 1 & Step 2 & Step 3 & Step 4 \\
\hline $\begin{array}{l}\text { Scenario } \\
\text { generation } \\
\text { (e.g. VAR or } \\
\text { GVAR } \\
\text { model) }\end{array}$ & $\begin{array}{l}\text { Factor Model } \\
\text { for bank asset } \\
\text { return or } \\
\text { risk } \\
\text { indicators }\end{array}$ & $\begin{array}{l}\text { CCA model } \\
\text { for Banks }\end{array}$ & $\begin{array}{l}\text { Impact on bank } \\
\text { credit risk, } \\
\text { (implicit put } \\
\text { and spread) and } \\
\text { on bank equity } \\
\text { capital }\end{array}$ \\
\hline
\end{tabular}

Macroeconomic scenarios are generated with a VAR, GVAR model ${ }^{18}$ or other model (Step 1) which are used in the factor model (Step 2) for the bank's assets to estimate impact on the bank's assets (Step 3) and its credit risk (implicit put option) and on the bank's equity capital (Step 4).

Example of Banking Stability Stress-Testing with Links to the Corporate and Household Sub-sectors - If there is sufficient data on corporate sub-sector and household sector balance sheets, a variation of the previous approach to first calibrate the CCA models for key financial institutions (as before) and calibrate the corporate subsector and household sector CCA balance sheets. The next step is to use data on exposures of banks to various sub-sectors to provide the links between bank assets and the risky debt obligations of the borrowers. Risk is transmitted by the changing value of the implicit put options in the borrower's risky debt. A factor model could be estimated for the time-series of corporate and household sector assets returns and used in conjunction with macroeconomic scenarios similar to the previous approach described above. $^{19}$

\section{Example of Stress-Testing and Assessing Capital Adequacy Using CCA}

Models of Financial Institutions - One major goal of financial sector stress-testing is to assess capital adequacy of various institutions under different potential shocks. Shocks to financial institution assets and asset volatility and/or interest rates and other parameters can be used in the CCA model to measure the impact on capital adequacy. An advantage of using CCA models for financial institutions is that the capital adequacy can be related to asset level, asset volatility, and default probability on the institution's liabilities and other factors. This way to calculate capital adequacy has been extended to include interest rates, interest rate volatility and correlation of asset return with interest rates by van Deventer and Imai (1997, and 2003) and Belmont (2004) using the Merton-STV model.

\footnotetext{
${ }^{18}$ Structural CCA model is a useful framework for understanding the co-movements of assets, equity, credit risk, and key volatility measures which might provide useful insights for structuring VAR models and designing shocks/innovations in those models.

${ }^{19}$ Van den End, Central Bank of the Netherlands and Central Bank of Chile. Also see Gapen et. al. (2004).
} 
The financial stress testing process commonly used by central banks and banking supervisors use various models to measure the change in expected default probability of the obligors, usually representative corporates or corporate sub-sectors. The default probabilities are then used with estimates of exposure and loss given default in a model of bank credit losses (e.g. Credit Risk Plus) to estimate the impact on economic capital. ${ }^{20}$ Calibrated CCA models of financial institutions can be used to estimate capital adequacy without the need for detailed data on default probabilities or loss given default of obligors. As pointed out by van Deventer, "In the capital allocation [using the MertonSTV model], note that we didn't use the probability of default or the loss given default in allocating capital. We don't need to, because the probability of default and loss given default are both implied by the STV model and the value of asset volatility and interest rate and correlation." This makes CCA a potentially useful tool when detailed data on obligor exposures, default probabilities, or loss-given-default is not available.

\section{Integrating Financial Risk Models and Indicators with Macro Models}

Credit risk, and the market risk of the claims held in agents' financial portfolios, are generally absent even in the majority of state-of-the-art macroeconomic models. This omission can be serious one, because risk impacts valuation, and changes in the valuation of the claims held by agents, and of their net worth, impacts their decisions to spend, save, and invest. Recent work has begun to address the linkage of macroeconomic and financial stability models. ${ }^{21}$

In order to understand the interaction of balance sheet risk and the macroeconomy a promising area of future research is the integration of the financial risk analytic models and indicators with traditional macroeconomic models. Such integrated models need to address the different mathematical nature of macroeconomic models and finance models. Macroeconomic models are primarily stock-flow models in discrete time and are usually geared to try to forecast the mean of macroeconomic variables. Financial risk analytics, on the other hand, focus on the probability of assets, following a random walk, will fall below a certain threshold or default barrier and therefore volatility (the second moment) is critical in risk analysis, not the mean (first moment). CCA is a framework with volatile assets relative to a distress barrier using option pricing concepts to calculate credit risk indicators. While there can be different levels of aggregation of the CCA balance sheets, whatever level of aggregation is chosen, the time pattern of the following could be calculated and used with macroeconomic models:

- $\quad$ Time series of CCA balance sheet components (assets, asset volatility, distress barriers and implicit put and call options) and sensitivity measures (e.g. delta and vega);

\footnotetext{
${ }^{20}$ See Sorge (2004). Work at the ECB by Castren et. al. (2007) uses MKMV median default probability for various corporate sectors with a VAR or Global VAR. Also see Pesaran et. al. (2004) and Alves (2005).

${ }^{21}$ See Bardsen, Lindquist and Tsomocos (2006), Goodhart et. al. (2004, 2006a, 2006b), Tsomocos (2003) and Haldane et. al. (2007), Swinburne (2007), and IMF (2007).
} 
- $\quad$ Time series of CCA derived credit risk indicators (distance-to-distress, estimated default probability, CCA credit spreads, etc.). Ways to aggregate credit risk indicators is described in Box 3;

- $\quad$ Time series of market indicators such as observed CDS and bond spreads or market risk appetite indicators (such as VIX or other indicators).

These financial risk analytic measures can be related to the time pattern of macroeconomic variables using econometric techniques to study leads, lags, or contemporaneous correlation. Various channels could be investigated using econometrics. For example, the channel from GDP to corporate and household's risk indicators, to financial sector risk indicators could be modeled. The reverse channel from financial sector (balance sheets and risk indicators), to the corporate and household sector balance sheet ${ }^{22}$ components, and risk indicators, and the relationship to GDP over the economic cycle could be investigated.

\section{Box 3 Aggregation of Credit Risk Indicators (CRIs)}

In order to have a tractable measure of system risk for use with macroeconomic models and for financial stability analysis the CCA credit risk indicators of a portfolio of individual financial institutions (or corporate firms) must be aggregated together. There are several ways to measure the system risk by aggregating the risk indicators of individual banks or institutions.

- Weight the individual default probabilities (EDFs from MKMV or other default probability estimate) by the implied assets of each bank/financial institution to get a system risk indicator.

- Weight the distance-to-distress for each institution by the implied assets of each bank/financial institution to get a system risk indicator.

- $\quad$ Use the median EDF for the sub-sector or group, e.g. as calculated by MKMV.

- Sum of the implicit put options of a portfolio of institutions to get the system expected loss for a given horizon period.

- Calculate an Nth to default indicator. The time pattern of default risk indicators for a portfolio of individual financial institutions can be used to understand the default correlations and get a credit risk indicator which is the probability of $\mathrm{N}$ defaults over a specific horizon period.

- $\quad$ Calculate the joint distribution of default probabilities in a portfolio of financial institutions. (For example, the joint probability modeled with the portfolio multivariate density developed by Segoviano).

\footnotetext{
${ }^{22}$ The dynamics of corporate and household borrowing levels are directly related to distress barriers in the
} CCA model. 


\section{Financial Risk Analytic Indicators and Monetary Policy Models}

Financial stability models and monetary stability models, by their nature, are very different frameworks. There is keen interest in relating these two types of analysis, but no consensus on how it can be done.

The primary tool for macroeconomic management is the interest rates set by the central bank. Simple model-based monetary policy models are widely used by central banks to understand macroeconomic and interest rate relationships. ${ }^{23}$ A simple four module monetary policy model of this type consists of an equation for the GDP output gap, an equation for inflation, an equation for exchange rate and real interest rates, and a Taylor rule for setting the domestic policy rate. The domestic policy rate is a short-term interest rate set by the central bank, such as the Federal Funds rate in the United States.

Since the economy and interest rates affect financial sector credit risk, and the financial sector affects the economy, an important issue is whether credit risk indicators (e.g. CRIs described in Box 3) should be included in monetary policy models and, if so, how. Including an aggregate credit risk indicator in the GDP gap equation and testing whether or not the coefficient is and important first step to get a better understanding of how the financial sector credit risk affects GDP. The next step could be to add a fifth equation relating the CRIs to GDP and interest rates (this could draw on analysis from the previous section relating financial risk indicators to macroeconomic variables).

Using past data, it might be interesting to include the CRI in the policy rate reaction function to examine whether financial stability appears to have been taken into account when setting interest rates in the past. A variation of this approach is being investigated in research department of the Central Bank of Chile. ${ }^{24}$ The approach taken in the Central Bank of Chile is to first estimate the distance-to-distress for the banking system (each individual bank's distance-to-distress from a CCA model is weighted by bank implied assets). The distance-to-distress for the banking system is included in the GDP gap equation and in the policy rate reaction function. The model parameters are then estimated using historical data, including the distance-to-distress indicator. The approach can be used to examine the tradeoffs between GDP, inflation, and distance-todistress for the banking system. ${ }^{25}$

Outputs of the sovereign CCA model include an estimate of the risk premium on government local-currency debt. The risk premium on the government local-currency debt is embedded in the nominal interest rate, which in turn affects the exchange rate, which is part of the GDP gap and inflation equations (first and second equations in the simple monetary policy model). This issue is important for certain emerging market countries (e.g. Brazil and Turkey). ${ }^{26}$ These are promising areas for further research. ${ }^{27}$

\footnotetext{
${ }^{23}$ A good summary is in Berg, Karam and Laxton (2006).

${ }^{24}$ Restrepo, Luna, and Gray (forthcoming).

${ }^{25}$ A related issue is whether an indicator of market risk appetite such as the VIX should be included in monetary policy models along with the credit risk indicator. This could help estimate the impact of the credit risk indicator on the GDP gap, adjusted for changes in risk appetite.

${ }^{26}$ See Gray and Malone (forthcoming) and Favero et. al. (2003).
} 
A final point we will touch on is the feedback of monetary policy and changes in interest rates on the CCA balance sheet values and risk indicators. CCA models that incorporate changes in interest rates (such as the Merton-STV model and/or factor model for asset return with interest rates as one factor), can be used to estimate the second round effects on credit risk of financial institutions in response to changes in interest rates.

\section{Conclusions}

This paper proposes a new approach to improve the way central banks can analyze and manage the financial risks of a national economy. It is based on the modern theory and practice of contingent claims analysis (CCA), which is successfully used today at the level of individual banks by managers, investors, and regulators. The basic analytical tool is the risk-adjusted balance sheet, which shows the sensitivity of the enterprise's assets and liabilities to external "shocks." The sectors of an economy are viewed as interconnected portfolios of assets, liabilities, and guarantees - some explicit and others implicit. The CCA approach is well-suited to capturing such "non-linearities" and to quantifying the effects of asset-liability mismatches within and across institutions. Risk-adjusted CCA balance sheets facilitate simulations and stress testing to evaluate the potential impact of policies to manage systemic risk. The time pattern of CCA balance sheet components, risk indicators, and sensitivity parameters can be integrated with macroeconomic models. The inclusion of financial system risk indicators and other financial risk parameters into simple monetary policy models is explored.

\footnotetext{
${ }^{27}$ There are several other interesting routes to take in linking risk analytics more closely with macroeconomic models. These include incorporating default risk and a risk premium into the MundellFleming model to separate out the effects of changes in interest rates due to changes in the market for liquidity, and changes in interest rates due to changes in the risk premium on debt (See Gray and Malone, forthcoming).
} 


\section{Annex - Estimating Implied Assets and Volatility, Default Probabilities and Extensions of the Merton Model}

This Annex provides details on estimating implied assets and asset volatility and extensions of the Merton Model.

\section{Calculating Implied Assets and Implied Asset Volatility}

The value of assets is unobservable, but it can be implied using CCA.

In the Merton Model for firms, banks and non-bank financials with traded equity use equity, $J$, and equity volatility, $\sigma_{J}$, and the distress barrier in the following two equations to solve for the two unknowns A, asset value, and $\sigma_{A}$, asset volatility. (See Crouhy, Mark and Galai (2000)).

$$
\begin{gathered}
J=A_{0} \mathrm{~N}\left(d_{1}\right)-\bar{B} \mathrm{~N}\left(d_{2}\right) \\
J \sigma_{J}=A \sigma_{A} N\left(d_{1}\right)
\end{gathered}
$$

\section{Extensions of the Merton Model}

Numerous extensions of the original Merton Model have been developed that relax certain assumptions in the original model. Restrictions of the model include the assumptions that: (i) default can occur only at the maturity date of the debt; (ii) there is a fixed default barrier; (iii) there is a constant risk-free rate; and, (iv) asset volatility is constant. Cossin and Pirotte (2001) provide a good summary of extensions of the Merton Model. Black and Cox (1976) extended the Merton Model to relax the assumptions (i) and (ii) above by introducing a "first passage time" model where default can occur prior to the maturity of the debt if the asset falls below a specified barrier function for the first time.

Although the strict theoretical condition in the Merton Model for default is that the value of assets is less than the required payments due on the debt, in the real world, default typically occurs at much higher asset values, either because of a material breach of a debt covenant or because assets cannot be sold to meet the payments ("inadequate liquidity") or because the sovereign decides to default and induce a debt renegotiation rather than sell assets. To capture these real-world conditions for default in the model, we specify a market value of total assets at which default occurs. We call this level of assets that trigger default the "distress barrier." This barrier can be viewed as the present value of the promised payments discounted at the risk-free rate. The approach used in the KMV model sets the barrier level equal to the sum of the book value of short-term debt, promised interest payments for the next 12 months, and half of long-term debt (see Crouhy, et. al. (2000) and KMV (1999, 2001)).

In the 1990s the KMV model was based the VK model (Vasicek and Kealhofer) which has multiple layers of liabilities and several confidential features. MKMV's EDF 
(expected default frequency) credit measure is calculated using an iterative procedure to solve for the asset volatility. This distance-to-distress was then mapped to actual default probabilities using a database of detailed real world default probabilities for many firms. The MKMV distance-to-distress and the CEDF (cumulative expected default probabilities) are calculated as follows:

$$
\begin{gathered}
D D_{K M V}=f\left(\frac{\ln \left(A_{0} / B_{t}\right)+\left(\mu_{A}-\sigma_{A}^{2} / 2\right) t}{\sigma_{A} \sqrt{t}}\right) \\
C E D F_{t}=f\left(D D_{K M V}(t)\right)
\end{gathered}
$$

Note that this definition of $D D_{K M V}$ includes the real drift of the asset, $\mu_{A}$, whereas the distance-to-distress from the Merton approach has $r$ for the asset drift. Since MKMV estimates the actual default probabilities, the risk neutral default probabilities are calculated from the correlation of the implied asset with the market, the market Sharpe Ratio, and time horizon.

The CreditGrades model (2002) includes a diffusion of a firm's assets and a first passage time default with a stochastic default barrier. The model was modified to incorporate equity derivatives (Stamicar and Finger 2005). Recent research has studied the relationship between the volatility skew implied by equity options and CDS spreads (Hull et. al. 2004). They establish a relationship between implied volatility of two equity options, leverage and asset volatility. This approach is, in fact, another way of implementing Merton's Model to get spreads and risk-neutral default probabilities directly from the implied volatility of equity options. A similar approach using several equity options is discussed in Zou (2003).

The Merton Model has been extended to include stochastic interest rates as well. Shimko, Tejima, and Van Deventer (1993) include a Vasicek interest rate term structure model which relaxes assumption (iii) above allowing the risk free interest rate to change and including the correlation of asset return with the interest rate. There are two stochastic factors, the asset and the interest rate and this model is frequently called the STV model. This closed form model is a very useful extension by including the impact of changing interest rate term structures. Longstaff and Schwartz (1995) take the Black and Cox (1976) model and add in stochastic interest rates, similar to the way STV includes interest rates. 


\section{References}

Alves, I. 2005. "Sectoral Fragility: Factors and Dynamics.” BIS Papers, 22

Aspachs, O., C. Goodhart, D. Tsomocos, and L. Zicchino. 2006. "Towards a Measure of Financial Fragility." Annals of Finance Special Issue, Springer-Verlag.

Bardsen, G., K-G. Lindquist, and D.P. Tsomocos. 2006. "Evaluation of Macroeconomic Models for Financial Stability Analysis.” Working Paper, Financial Markets Department, Norges Bank, Oslo, Norway.

Belmont, D. 2004. Value Added Risk Management in Financial Institutions, Wiley Finance.

Berg, A., P. Karam, and D. Laxton. 2006. "A Practical Model-Based Approach to Monetary and Policy Analysis-Overview.” IMF Working Paper 06/80, Washington D.C.

Berg, A., P. Karam, and D. Laxton. 2006. "A Practical Model-Based Approach to Monetary and Policy Analysis-How-To Guide.” IMF Working Paper 06/81, Washington D.C.

Bernanke, B, M. Gertler and S. Gilchrist. 1999. "The financial accelerator in a quantitative business cycle framework." In Handbook of Macroeconomics, ed. J.B. Taylor and M. Woodford. Amsterdam: Elsevier Science.

Black, F. and J. Cox. 1976. "Valuing Corporate Securities: Some Effects of Bond Indenture Provisions." Journal of Finance, 31(2): 351-367.

Black, F. and M. Scholes. 1973. "The Pricing of Options and Corporate Liabilities.” Journal of Political Economy, 81 (May-June): 637-54.

Bodie, Z. and R. Merton. 2000. Finance. New Jersey: Prentice Hall, Upper Saddle River.

Bodie, Zvi. 2006. “On Asset-Liability Matching and Federal Deposit and Pension Insurance.” Federal Reserve Bank of St. Louis Review, July/August.

Castren, O., S. Dees, and F. Zaher. 2007. "How do Global Macro-Financial Shocks Affect Corporate Sector Expected Default Frequencies in the Euro Area?" ECB 2007.

Cossin, D., and H. Pirotte. 2001. Advanced Credit Risk Analysis, John Wiley \& Sons, Ltd.

CreditGrades. 2002. CreditGrades Technical Document, RiskMetrics Group.

Crouhy, Michel, Dan Galai and Robert Mark. 2000. Risk Management. New York: Mc Graw Hill. 
Draghi, Mario, Francesco Giavazzi, and Robert C. Merton. 2003. Transparency, Risk Management and International Financal Fragility, Vol. 4, Geneva Reports on the World Economy. International Center for Monetary and Banking Studies.

Favero, C., and F. Giavazzi. 2003. "Monetary policy when debt and default risk are high: lessons from Brazil.” London School of Economics Seminar Paper, May 16. http://cep.lse.ac.uk/seminarpapers/22-05-03-GIA.pdf.

Gapen, Michael T., Dale F. Gray, Cheng Hoon Lim, and Yingbin Xiao. 2004. "The Contingent Claims Approach to Corporate Vulnerability Analysis: Estimating Default Risk and Economy-Wide Risk Transfer.” IMF Working Paper 04/121. (Washington: International Monetary Fund).publications@imf.org.

Gapen, Michael T., Dale F. Gray, Cheng Hoon Lim, and Yingbin Xiao. 2005. "Measuring and Analyzing Sovereign Risk with Contingent Claims." IMF Working Paper 05/155. (Washington: International Monetary Fund) publications@imf.org.

Goodhart, C.A.E., P. Sunirand and D.P. Tsomocos. 2004. "A Model to Analyse Financial Fragility: Applications." Journal of Financial Stability, 1, 1-35.

Goodhart, C.A.E., P. Sunirand and D.P. Tsomocos. 2006a. "A Model to Analyse Financial Fragility." Economic Theory, 27, 107-142.

Goodhart, C.A.E., P. Sunirand and D.P. Tsomocos. 2006b. "A Time Series Analysis of Financial Fragility in the UK Banking System.” Annals of Finance, 2, 1-21.

Gray, D., R. C. Merton, and Z. Bodie. 2002. "A New Framework for Analyzing and Managing Macrofinancial Risks." Conference on Finance and the Macroeconomy, October 2002, NYU.

Gray, D., R.C. Merton, Z. Bodie. 2006. "A New Framework for Analyzing and Managing Macrofinancial Risks of an Economy," NBER paper \#12637 and Harvard Business School Working Paper \#07-026, October.

Gray, D., R.C. Merton, and Z. Bodie. Forthcoming. "Contingent Claims Approach to Measuring and Managing Sovereign Credit Risk." Journal of Investment Management Vol. 5, No. 4, pp.1-24, December 2007.

Gray, D. 2001. "Macrofinancial risk country report: Thailand, MFRisk and Macro Financial Risk Framework.” MFRisk document.

Gray, D., C.H Lim, E. Loukoianova, and S. Malone. Forthcoming. "A New Debt Sustainability Framework: Incorporating Balance Sheets and Uncertainty." IMF Working Paper 2006/7. IMF.

Gray, D. and S. Malone. Forthcoming. Macrofinancial Risk Analysis. UK: Wiley Finance. 
Gray, D. and J. Walsh. Forthcoming. "Factor Model for Stress-testing with a Contingent Claims Model of the Chilean Banking System.” IMF Working Paper 05/155.

(Washington: International Monetary Fund).

Haldane, A., S. Hall, and S. Pezzini. 2007. "A New Approach to Assessing Risks to Financial System Stability.” Financial Stability Paper No. 2.

Hull, J., I. Nelken, and A. White. 2004. “Merton's Model, Credit Risk and Volatility Skews." Journal of Credit Risk. Vol 1, No 1.

IMF. 2007. Global Financial Stability Report: "Financial Market Turbulence Causes, Consequences, and Policies.” October.

IMF. 2006. Gray, D. and M. Jones. Indonesia: Selected Issues Paper, Chapter III. "Measuring Sovereign and Banking Risk in Indonesia: An Application of the Contingent Claims Approach.”In IMF Country Report No. 06/318, August. publications@imf.org.

KMV Corporation. 1999 and 2001. "Modeling Default Risk.” KMV Corp, Crosbie, Peter, KMV. (Now Moody's-KMV).

Longstaff, F. and E.S. Schwartz. 1995. "A Simple Approach to Valuing Risky Fixed and Floating Rate Debt.” Journal of Finance, 50(3): 789-819.

Merton, R.C. 1973. "Theory of Rational Option Pricing.” Bell Journal of Economics_and Management Science, 4 (Spring): 141-83. (Chapter 8 in Continuous-Time Finance).

Merton, R.C. 1974. "On the Pricing of Corporate Debt: The Risk Structure of Interest Rates.” Journal of Finance, 29 (May), pp. 449-70. (Chapter 12 in Continuous-Time Finance).

Merton, R.C. 1977. "An Analytic Derivation of the Cost of Loan Guarantees and Deposit Insurance: An Application of Modern Option Pricing Theory." Journal of Banking and Finance 1 (June), pp. 3-11. (Chapter 19 in Continuous-Time Finance).

Merton, R. C. 1992. Continuous-Time Finance. Oxford, U.K.: Basil Blackwell, (Rev. ed.).

Merton, R.C. 1998. "Applications of Option-Pricing Theory: Twenty-Five Years Later." Les Prix Nobel 1997, Stockholm: Nobel Foundation; reprinted in American Economic Review, (June): 323-349.

Merton, R.C. and Z. Bodie.1992. "On the Management of Financial Guarantees." Financial Management, 21 (Winter): 87-109. 
Pesaran, M., T. Schuermann, and S. Wiener. 2004. "Modeling Regional Interdependencies Using Global Error Correcting Macroeconometric Model." Journal of Business and Economic Statistics, 22, 129-162.

Restrepo, J., L. Luna, and D. Gray. Forthcoming. "Including Banking System Risk Indicators in Monetary Policy Models: The Case of Chile." Unpublished Analysis Central Bank of Chile (working paper).

Segoviano, M., C. Goodhart, and B. Hofmann. 2006a. "Default, Credit Growth, and Asset Prices.” IMF Working Paper 06/223, International Monetary Fund, Washington, DC.

Segoviano, M. 2006b. "Portfolio Credit Risk and Macroeconomic Shocks: Applications to Stress Testing Under Data-Restricted Environments.” IMF Working Paper 06/283, International Monetary Fund, Washington, DC.

Shimko, David, N. Tejima, and D. van Deventer. 1993. "The Pricing of Risky Debt When Interest Rates are Stochastic." Journal of Fixed Income, September.

Sorge, M. 2004. "Stress testing financial systems: An overview of current methodologies." BIS Working Paper No. 165, Basel.

Stamicar, R. and C. Finger. 2005. "Incorporating Equity Options into the CreditGrades Model.” RiskMetrics Group.

Swinburne, M. 2007. "The IMFs Expereince with Macro Stress-Testing." Presentation at ECB High Level Conference on Simulating Financial Instability.

Tsomocos, D.P. 2003. "Equilibrium Analysis, Banking, and Financial Instability." Journal of Mathematical Economics, 39, pp. 619-655.

Van den End, W., and M. Tabbae 2005. "Measuring financial stability; applying the MfRisk model to the Netherlands.” De Nederlandsche Bank, WP No. 30, March.

Van Deventer, D. and K. Imai. 1997. Financial Risk Analytics. New York: McGraw-Hill Companies.

Van Deventer, D. and K. Imai. 2003. Credit Risk Models and the Basel Accords. Singapore: John Wiley and Sons, pp. 215-224.

Zou, J. 2003. "The Relationship between Credit Default Probabilty and Equity Volatility Surface," presentation at RISK conference in Boston. 
Dale Gray is the Sr. Risk Expert for the IMF Monetary and Capital Markets Department and President of MF Risk, Inc. and, MFRisk board members include Robert C. Merton and Zvi Bodie. Contact information for Dale Gray is email is dgray@imf.org and Dgray@MFRisk.com . Contact information for Robert Merton is rmerton@hbs.edu and Zvi Bodie is zbodie@bu.edu.

The authors would like to thank Sam Malone, Andrea Maechler, Chris Towe, Mark Swinburne, Matt Jones, John Kiff, Mark Levonian and Joe Zou (Taconic) for useful discussions and comments on the ideas presented in the paper. 